\title{
Ecological niche modelling of species of the rose gall wasp Diplolepis (Hymenoptera: Cynipidae) on the Iberian Peninsula
}

\author{
SARA SARDÓN-GUTIÉRREZ ${ }^{1}$, Diego GIL-TAPETADO ${ }^{1,2}$, José F. GÓMEZ ${ }^{1}$ and José L. NIEVES-ALDREY ${ }^{2}$ \\ ${ }^{1}$ Departamento de Biodiversidad, Ecología y Evolución, Facultad de Ciencias Biológicas, Universidad Complutense de Madrid, \\ 28040 Madrid, Spain; e-mails: sarasard@ucm.es; diego.gil@ucm.es; jf.gomez@bio.ucm.es \\ ${ }^{2}$ Museo Nacional de Ciencias Naturales (CSIC), José Gutiérrez Abascal 2, 28006 Madrid, Spain; \\ e-mail: mcnna38@mncn.csic.es
}

Key words. Hymenoptera, Cynipidae, Diplolepis, species distribution modelling, gall-inducing wasps, Spain, Rosaceae, habitat complementarity

\begin{abstract}
Diplolepis (Hymenoptera: Cynipidae) are gall wasps that induce conspicuous galls on Rosa spp. (Rosaceae). These species are distributed globally and in Europe some are especially common and are founder organisms of biological communities composed of different insects. However, the ecological niches of these species have not been studied in detail. We modelled the potential distributions of these species using the locations of the galls of the four most abundant species of Diplolepis on the Iberian Peninsula (Diplolepis mayri, Diplolepis rosae, Diplolepis eglanteriae and Diplolepis nervosa, the galls of latter two are indistinguishable) using four different algorithms and identified the resulting consensus for the species. We compared the potential distributions of these species, considering their spatial complementarity and the distributions of their host plants. We found that $D$. mayri and $D$. eglanteriae/nervosa have complementary distributions on the Iberian Peninsula. The former species is found in the Mediterranean region, while $D$. eglanteriae and $D$. nervosa are distributed mainly in the Eurosiberian region. Diplolepis rosae has the widest distribution on the Iberian Peninsula. Our models constitute the first effort to identify suitable areas for species of Diplolepis species on the Iberian Peninsula and could be useful for understanding the evolutionary ecology of these species throughout their distribution in the western Palearctic.
\end{abstract}

\section{INTRODUCTION}

The Cynipidae family comprises approximately 1,500 species worldwide, mainly distributed in temperate areas in the Northern Hemisphere (Ronquist, 1999; Csoka et al., 2005; Melika, 2006). On the Iberian Peninsula and Balearic Islands there are 29 genera and 147 species of Cynipidae (Nieves-Aldrey, 2001a; Nieves-Aldrey et al., 2006, 2012, unpubl.). Most of the cynipids (86\%) are associated with oak trees (Fagaceae), 7\% induce galls on the genus Rosa L., and the remaining 7\% are associated with different camephytic and herbaceous plants of the families Rosaceae, Asteraceae, Lamiaceae, Papaveraceae, Valerianaceae and Aceraceae (Folliot, 1964; Shorthouse, 1973; Nieves-Aldrey, 1981, 2001a). The Diplolepidini tribe is strictly associated with Rosaceae and includes two genera, Diplolepis Geoffroy, 1762 and Liebelia Kieffer, 1903, the species of which induce galls only on plants of the genus Rosa, but are not highly host-specific within this genus (Pujade-Villar, 1993). Among these genera, the most diverse and widespread is Diplolepis. A total of fifteen species of this genus are recorded in the Palearctic (Belizin, 1957; Pujade-Villar, 1993; Nieves-Aldrey, 2001a; Abe et al., 2007; Pujade-Villar et al., 2020) and thirty-one in the
Nearctic (Burks, 1979; Csóka et al., 2005). Six species of Diplolepis are common and widely distributed in Europe, but only five species are recorded on the Iberian Peninsula (Nieves-Aldrey, 2001a) (Fig. 1): Diplolepis eglanteriae (Hartig, 1840), Diplolepis nervosa (Curtis, 1838), Diplolepis rosae (Linnaeus, 1758), Diplolepis mayri (Schlechtendal, 1877) and Diplolepis spinosissimae (Giraud, 1859). In addition to the western European species, there is an additional Diplolepis species, Diplolepis fructuum (Rübsaamen, 1896), which is distributed from Ukraine to the Anatolian Peninsula and in the neighbouring regions of the Caucasus and Kazakhstan (Nieves-Aldrey, 2001a; Lotfalizadeh et al., 2006; Güçlü et al., 2008; Katılmış \& Kıyak, 2010; Todorov et al., 2012). The second member of the Diplolepidini tribe, the predominantly Asian genus Liebelia, has only one species in Europe, Liebelia cavarai (Kieffer, 1895), which is restricted to the island of Sardinia (Vyrzhikovskaja, 1963).

Galls of the European Diplolepis may be categorized into two morphological groups according to the plant organs they attack and the shape and structure of the galls they induce, which correspond with different extant phylogenetic lineages (Zhang et al., 2019). D. eglanteriae, D. 
nervosa and $D$. spinosissimae induce mainly small spherical and unilocular galls on leaves, and D. rosae, D. mayri and $D$. fructuum cause larger, multilocular galls on stems, leaves or hips.

D. eglanteriae and D. nervosa form a complex of cryptic galls that are morphologically indistinguishable, potentially leading to misidentification. Both species are univoltine and bisexual. On the other hand, the galls of $D$. spinosissimae are produced on the leaves, the fruits and sometimes the stems of different species of the genus Rosa, mainly shrubs of Rosa pimpinellifolia L.

The species $D$. rosae and D. mayri induce conspicuous and striking galls and are thus the most collected and recorded within the genus. The galls of both species develop on buds or twigs, but sometimes on leaflets or fruits. The galls of D. mayri (Fig. 1G) have a sparse coating of stiff spines instead of the filamentous appendix of the so-called 'rose bedeguar' galls of $D$. rosae (Fig. 1D-F). The life cycle of both species is univoltine, but their modes of reproduction vary with their geographical range, particularly on the Iberian Peninsula. While males of $D$. rosae are very scarce or virtually absent in most areas on the Iberian Peninsula, the sex ratio of this species is closer to $1: 1$ in the rest of Europe. In fact, some studies in other areas have linked latitude with the relative presence/abundance of males of D. rosae (Askew, 1960; Stille, 1984, 1985). Males of $D$. mayri (Fig. 1A) are not abundant in non-Iberian Europe, but other authors have discovered differences in the reproductive biology of this species on the Iberian Peninsula, where it does not undergo thelytokous parthenogenesis as it does in other countries. Instead, the Iberian D. mayri has a bisexual generation and a sex ratio close to $1: 1$ (PujadeVillar, 1983; Nieves-Aldrey, 1989; Nieves-Aldrey, 2001a).

From the biogeographical and macroecological point of view, determining the potential distribution of organisms is an important tool for the ecological and biological conservation of animals (Guisan \& Zimmermann, 2000; Guisan et al., 2006; Peterson, 2006). Using mathematical algorithms to model the potential distribution of species has allowed the determination of those areas where there is a greater probability of finding them. Niche models, suitability models or predictive habitat distribution models are empirical or mathematical approximations of the ecological niche of a species constructed from their presence and/ or absence records and variables that limit and define this niche (Araújo \& Guisan, 2006; Austin, 2007; Peterson et al., 2011).

It is important that these niche models are based on environmental conditions in the regions studied and that the potential distribution models provide a distribution of habitat suitability for each species (Franklin, 2009; Zimmermann et al., 2010). The variable selection procedure is quite important since these variables are going to limit and define the habitat of a species. In addition, selecting appropriate predictor variables will decide if the model is essential for predicting species distributions (Guisan \& Zimmermann, 2000; Jiménez-Valverde et al., 2011). Climatic variables are probably the main contributors to species niche delimitation at a large scale (Barbet-Massin et al., 2013).

Currently, there are a few cynipid ecological models, all of them related to Fagaceae hosts (Rodríguez et al., 2015; Gil-Tapetado et al., 2018). This paper presents, for the first time, an accurately niche suitability modelling of Diplolepis communities on Rosaceae hosts.

The main aim of this study is to determine potentially favourable areas for gall-inducing cynipids associated with shrubs of the family Rosaceae on the Iberian Peninsula. This objective is achieved by comparing different ecological models incorporating predictive climatic and environmental variables, Diplolepis records and a suitability model of host plants, which is used to limit the distribution. These favourability models are used to analyse the association of species of Diplolepis with biotic and abiotic variables and draw conclusions about their distribution on the Iberian Peninsula.

\section{MATERIALS AND METHODS}

\section{Selection of presence data}

To create the niche models, we compiled a dataset of the presence of five species of Diplolepis recorded in southern Europe: D. eglanteriae/nervosa, D. spinosissimae, D. rosae and D. mayri (Fig. 1). This was compiled using the published and georeferenced records of each species. All records for synonymous species names were also considered acceptable and included in the data matrix (Nieves-Aldrey, 2001a). This data was compiled from different sources up to 2017 (Table 1, Fig. 2A-D, Table S1). As species of Diplolepis are dependent on Rosa species, we used the modelled distribution of the host plant to define the limits of the cynipid distributions. Records of Rosa, consisting of 17,943 presences (Fig. 2E), were compiled from GBIF (Global Biodiversity Information Facility) datasets (GBIF Data Portal, 2016) and used in niche models. Both cynipid and host plant records were cleaned by eliminating geographically redundant (we included only one presence record per $\mathrm{km}^{2}$ ) and low accuracy georeferenced data.

\section{Selection of variables}

Bioclimatic and environmental variables can be used to predict the presence of each species of gall wasp. In the present study, different variables were used to model cynipid-gall and host Rosa, because it is important to distinguish those variables that have a direct effect on cynipid biology and those that influence the wasp through its host plant (Rodriguez et al., 2015; Gil-Tapetado et al., 2018).

The WorldClim version 1.4 (Hijmans et al., 2005) variables at a resolution of 30 arc seconds were used in the niche models of Diplolepis. As they emerge from their galls in spring (March, April, and May), only the spring variables Bio04 (temperature seasonality), Bio08 (mean temperature in wettest quarter), Bio13 (precipitation in wettest month), Bio15 (precipitation seasonality) and Bio16 (precipitation in wettest quarter) were used in these analyses, because they directly affect adult Diplolepis. Galls isolate the wasps from external environmental conditions, although some variables, such as snow cover, glycerol concentration or mild winter temperatures, affect the survival of those that overwinter in galls (Somme, 1964; Shorthouse, 1980; Williams et al., 2003). The free-living stage (i.e., adult cynipid), however, is affected directly by bioclimatic conditions (Shorthouse \& Rohfrisch, 1992). 

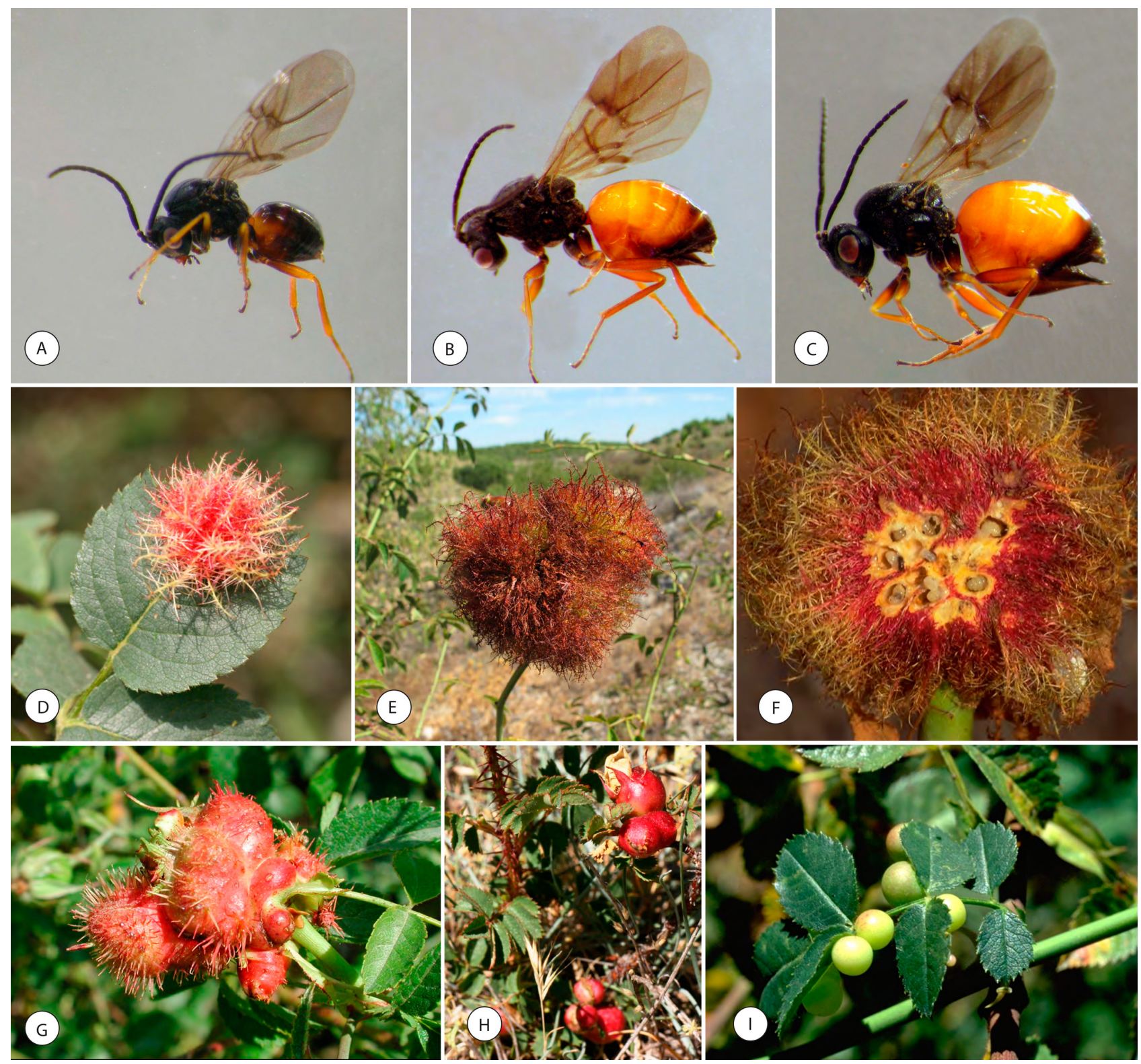

Fig. 1. Adults and galls of species of Diplolepis. A - adult male Diplolepis mayri; $\mathrm{B}$ - adult female $D$. mayri; $\mathrm{C}$ - adult female $D$. rosae; $\mathrm{D}-\mathrm{F}$ - galls of $D$. rosae and a section of a gall; $\mathrm{G}-D$. mayri gall; $\mathrm{H}-D$. spinosissimae gall; I - galls of $D$. eglanteriae/nervosa.

We used cluster dendrogram analysis of correlation distances to identify possible correlation biases between the variables. First, we chose all the variables that exceeded a value of 0.3 (or less than $70 \%$ correlation). Second, we selected all the uncorrelated variables (those variables that did not form a cluster); finally, we chose the variable with the greatest biological significance for Diplolepis from the clusters of correlated variables. In cases in which a variable did not have a clear biological meaning, the most derived variable was chosen (i.e., the variable that refers to a specific period of the year). Bio16 was excluded from the modelling of Diplolepis due to its high correlation with the rest of the variables (Fig. 3A). In addition, we applied a forward elimination process, variance inflation factor (VIF), to the variables. VIF measures how much the variance in a regression coefficient increases when predictors are correlated. We computed the VIF of the variables using $\mathrm{R}$ version v 3.3.1 ( $\mathrm{R}$ Development Core Team, 2008) and RStudio 0.99.903 (RStudio Team, 2016) in the package HH 3.1-32 (Heiberger \& Holland, 2015). The threshold value of 5 was used to determine which variables were strongly corre- lated with other factors, thereby indicating that it was appropriate to eliminate them from the analysis (Kutner et al., 2004; O'Brien, 2007; Lin et al., 2011). All the variables in the dendrogram satisfied the threshold value condition (VIF $>5$ ) and no variable was excluded from the analysis.

The selection of environmental variables for the construction of the Rosa model was difficult because these plants are widely distributed and it is a group with many species (Zhang \& Gandelin, 2003; Yan et al., 2005; Koopman et al., 2008). The ecological and edaphic conditions selected are general, which makes it difficult to determine those conditions that are most likely to influence its presence (Castroviejo et al., 1998). We used the modelling methods previously mentioned and selected the most general climatic variables from WorldClim (Bio01 (annual mean temperature), Bio02 (mean diurnal range), Bio03 (isothermality), Bio07 (temperature annual range) and Bio12 (annual precipitation)) and other non-climatic variables (available water capacity (ESDB, 2004), percentage of clay (ESDB, 2004), lithology (IGME, 2020), proximity to water masses (rivers, lakes, reservoirs and 
Table 1. Record of presence of different species of Diplolepis on the lberian Peninsula and the sources of the information (Source) from which they were compiled. $\mathrm{N}$ indicates the number of records per source.

\begin{tabular}{|c|c|c|c|}
\hline Species & Source & $\mathrm{N}$ & Presence data \\
\hline Diplolepis spinosissimae & $\begin{array}{l}\text { Nieves-Aldrey (1986, pers. comm.) } \\
\text { Pujade-Villar }(1991,1993,1996)\end{array}$ & $\begin{array}{l}5 \\
3\end{array}$ & 8 \\
\hline $\begin{array}{l}\text { Diplolepis eglanteriae } \\
\text { and } \\
\text { Diplolepis nervosa }\end{array}$ & $\begin{array}{c}\text { Cogolludo (1921) } \\
\text { Nieves-Aldrey }(1984,1989,1995,2001 b, \text { pers. comm.) } \\
\text { Pujade-Villar (1991, 1993, 1996) } \\
\text { Tavares (1931a, b) } \\
\text { Vilarrúbia \& Vilarrúbia (1933) } \\
\text { BiodiversidadVirtual.org } \\
\end{array}$ & $\begin{array}{c}4 \\
36 \\
12 \\
13 \\
3 \\
47 \\
\end{array}$ & 115 \\
\hline Diplolepis mayri & $\begin{array}{c}\text { Cogolludo (1921) } \\
\text { Lázaro e Ibiza (1917) } \\
\text { Nieves-Aldrey (1984, 1986, 1989, 1995, 2001b, pers. comm.) } \\
\text { Pujade-Villar }(1983,1987,1991,1993,1996) \\
\text { Tavares }(1931 a, b) \\
\text { Vilarrúbia (1933, 1936) } \\
\text { BiodiversidadVirtual.org }\end{array}$ & $\begin{array}{c}5 \\
1 \\
55 \\
22 \\
1 \\
2 \\
61\end{array}$ & 147 \\
\hline Diplolepis rosae & $\begin{array}{c}\text { Codina (1920) } \\
\text { Cogolludo (1921) } \\
\text { Fernández de Gata (1901) } \\
\text { Lázaro e Ibiza (1917) } \\
\text { Nieves-Aldrey }(1981,1985,1986,1989,2001 \text { b) } \\
\text { Pujade-Villar }(1983,1987,1991,1993,1996) \\
\text { Tavares }(1931 a, b) \\
\text { Ventalló (1905) } \\
\text { Vilarrúbia \& Vilarrúbia (1933); Vilarrúbia (1936) } \\
\text { BiodiversidadVirtual.org } \\
\text { GBIF }\end{array}$ & $\begin{array}{c}1 \\
7 \\
1 \\
1 \\
76 \\
40 \\
16 \\
1 \\
2 \\
129 \\
8\end{array}$ & 282 \\
\hline
\end{tabular}

other continental water bodies) (modified from EEA, 2009) and land uses from CORINE Land Cover 2006 (EEA, 2012) resized to $1 \mathrm{~km}^{2}$ ). Bio2 and available water capacity were not included in the final set of variables (Fig. 3B).

\section{Modelling the distributions of species}

We used the following algorithms: generalized linear models (GLMs) (McCullagh \& Nelder, 1989), generalized additive models (GAMs) (Hastie \& Tibshirani, 1990, Yee \& Mitchell, 1991), random forest (RF) (Breiman, 2001) and MaxEnt (Phillips et al., 2006). The first three were created using $R$ version 3.3.1 ( $R$ Development Core Team, 2008) and RStudio version 0.99.903 (RStudio Team, 2016) in the packages dismo 1.1-1 (Hijmans et al., 2015), mgcv 1.8-12 (Wood, 2016) and randomForest 4.6-12 (Breiman et al., 2015), with 3,000 trees and a node number of 3. We used MaxEnt version 3.4.1 (Phillips \& Dudik, 2008) with the default configuration, including a regularization parameter of 1 and 10 replicates.

For both the Rosa and Diplolepis models, we performed background point generation tests following and improving upon the methodology of Gil-Tapetado et al. (2018), using the maximum and minimum values of the predictor variables as parameters of habitability for each species. The sum of the resulting areas between the maximum and minimum values of each predictive variable was classified as habitable area in which to generate random background points; the excluded areas were classified as nonhabitable zones in which to generate the pseudo-absences.

Four individual models (GLM, GAM, MaxEnt and RF) were developed for the host plant taxa (genus Rosa), D. rosa and $D$. mayri, and the group formed by $D$. eglanteriae and $D$. nervosa the galls of which are not externally morphologically distinguishable. We could not develop models for $D$. spinosissimae (Fig. 1H) because of the few records for this species from the Iberian Peninsula (Fig. 2D, Table 1). With respect to host plant taxa, models were made including different species of the genus Rosa.
We evaluated these models using area under the curve (AUC) statistics. Finally, we selected models that had a maximum suitability value of at least 0.80 to obtain an improved estimation of the potential geographic distribution of a species. The models selected for each species were joined to create an average consensus map.

ArcGIS 10.1 software (ESRI, 2011) was used to transform highly suitable areas (i.e., areas with a suitability greater than or equal to 0.70 ) indicated by the host plant consensus models into buffer zones of high suitability - i.e., zones with a radius of one kilometre around the presence data for Rosa, which constitute possible action areas for the species. Presence data for the genus Rosa were also included, and corresponding buffers with a one-kilometre radius were generated around the presence points. We overlapped this mask layer with each consensus model of Diplolepis species to obtain the final models. These results reflect the high and low probabilities of the presence of each cynipid within their host plant areas on the Iberian Peninsula.

The complementary maps of the Diplolepis species were developed in ArcGIS 10.1 (ESRI, 2011) based on the most favourable areas (areas with values greater than 0.70 ). Finally, these maps were combined by twos. In addition, the possible associations of environmental variables Bio04 (temperature seasonality), Bio15 (precipitation seasonality) and Biol6 (precipitation in wettest quarter) from WorldClim version 1.4 (Hijmans et al., 2005) with the potential distribution areas of the Diplolepis species were checked using boxplots in the ggplot2 package in RStudio.

\section{RESULTS}

The results from the RF, GLM and GAM algorithms were selected for the species $D$. eglanteriae/nervosa and $D$. rosae because they had a maximum suitability of more than 0.80 . In the case of $D$. mayri, only the results of the RF and GAM met this requirement. In all these cases, MaxEnt did not exceed a maximum suitability of 0.80 and we 

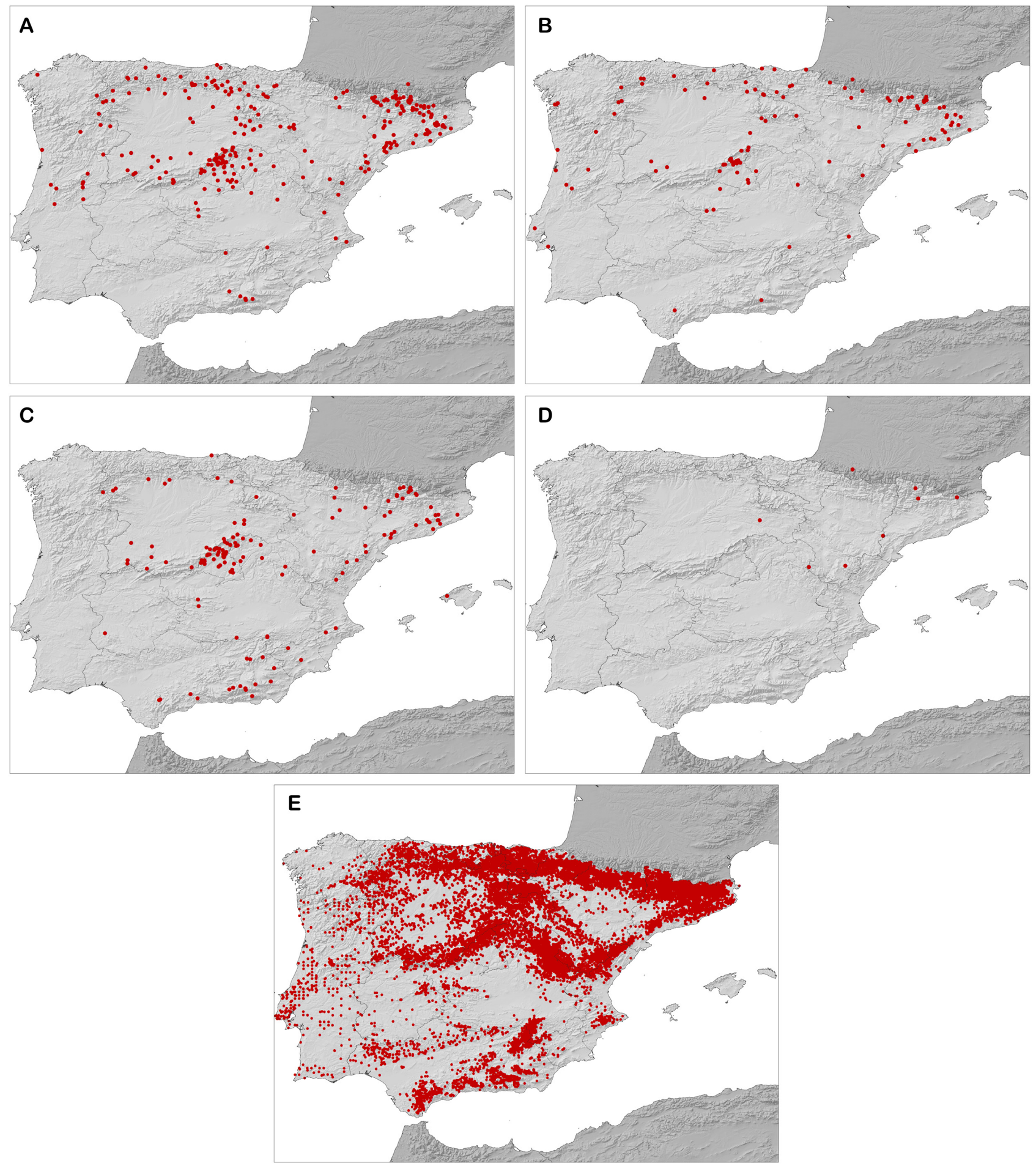

Fig. 2. Maps of the Iberian Peninsula showing the presence points for the species. A - Diplolepis rosae; B - Diplolepis eglanteriae/nervosa; C - Diplolepis mayri; D - Diplolepis spinosissimae; E - Rosa.

did not use this algorithm in the average consensus models. RF, GLM and GAM were selected to produce the final model for Rosa (Table 2).

The models indicate that southern areas of the Iberian Peninsula are more suitable for D. mayri (Fig. 4C) and northern areas more suitable for $D$. eglanteriae/nervosa (Fig. 4B), while D. rosae is a generalist, with highly suitable areas throughout the Iberian Peninsula (Fig. 4A).
Below, are the detailed results for each of the species of Diplolepis.

Diplolepis rosae (Figs 1C-F, 4A) is the most common species of this genus on the Iberian Peninsula. According to the presence points and areas of maximum suitability, this species occurs in areas with a mean annual temperature of approximately $11^{\circ} \mathrm{C}$ and annual precipitation of $700-800 \mathrm{~mm}$ and at an average altitude of approximately 900-1000 m a.s.l. In the areas in which D. rosae occurs, in 

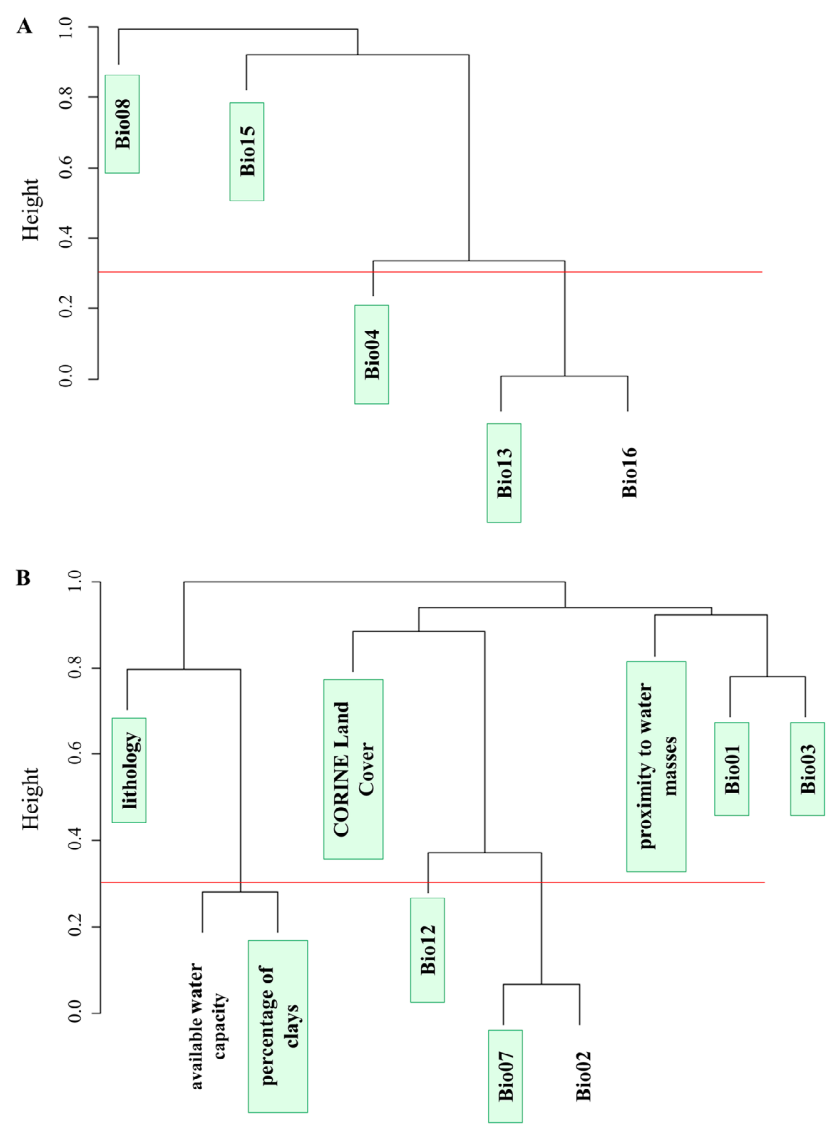

Fig. 3. Cluster dendrogram analysis based on the correlation coefficient distance for the following datasets. A - cynipid-related variables: Bio04 (temperature seasonality), Bio08 (mean temperature of wettest quarter), Bio13 (precipitation of wettest month), Bio15 (precipitation seasonality) and Bio16 (precipitation of wettest quarter) $\mathrm{B}$ - host plant-related variables: Bio01 (annual mean temperature), Bio02 (mean diurnal range), Bio03 (isothermality), Bio07 (temperature annual range), Bio12 (annual precipitation), available water capacity, percentage of clays, lithology, proximity to water masses and CORINE Land Cover (derived from land uses in the CORINE Land Cover 2006).
Table 2. Results of (AUC) area under the curve and the maximum suitability values of the four models used to develop each consensus model.

\begin{tabular}{lccc}
\hline Species & Model & AUC & $\begin{array}{c}\text { Maximum } \\
\text { suitability value }\end{array}$ \\
\hline \multirow{4}{*}{ Rosa } & GAM & 0.757 & 0.88 \\
& RF & 0.890 & 0.91 \\
& GLM & 0.734 & 0.85 \\
& Maxent & 0.623 & 0.59 \\
\hline \multirow{3}{*}{ niplolepis eglanteriae/ } & GAM & 0.715 & 0.91 \\
& GLM & 0.721 & 0.84 \\
& RF & 0.931 & 0.88 \\
& Maxent & 0.768 & 0.69 \\
\hline \multirow{3}{*}{ Diplolepis rosae } & GAM & 0.794 & 0.85 \\
& GLM & 0.796 & 0.81 \\
& RF & 0.905 & 0.85 \\
& Maxent & 0.764 & 0.69 \\
\hline \multirow{4}{*}{ Diplolepis mayri } & GAM & 0.814 & 0.86 \\
& RF & 0.911 & 0.93 \\
& GLM & 0.561 & 0.76 \\
& Maxent & 0.787 & 0.70 \\
\hline
\end{tabular}

the warmest quarter, the mean temperature was $19^{\circ} \mathrm{C}$ and there was approximately $160 \mathrm{~mm}$ of precipitation, while in the coldest quarter, the mean temperature was $4^{\circ} \mathrm{C}$ and there was approximately $190 \mathrm{~mm}$ of precipitation (Table $3)$. The presence areas for $D$. rosae are diverse, with suitability percentages of $>0.70$ in all areas. The areas with the most suitable ecological conditions are concentrated in the region of the Catalonian Pyrenees (north eastern Iberian Peninsula) and Montes de León (north western Iberian Peninsula) (Fig. 4A).

The most favourable areas for D. eglanteriae and D. nervosa (Fig. 1I, Fig. 4B) are in mountain ranges. The results indicate that areas in the Cantabrian Mountains and Pyrenees (in the north of Iberian Peninsula), both the Central and Iberian Mountain Ranges (central Iberian Peninsula), and part of the Baetic System (in the south of Iberian Peninsula) are the most suitable areas (with suitability percent-

Table 3. Different measurements of climatic variables Worldclim and altitude in the points of presence and of high suitability for the Diplolepis rosae, with the average value (AV), standard deviation (SD) and minimum (MIN) and maximum (MAX) values for each.

\begin{tabular}{|c|c|c|c|c|c|c|c|c|c|}
\hline \multirow{2}{*}{ Variable } & \multirow{2}{*}{ Code } & \multicolumn{4}{|c|}{ PRESENCE DATA } & \multicolumn{4}{|c|}{ HIGH SUITABILITY } \\
\hline & & $\mathrm{AV}$ & SD & MIN & MAX & AV & SD & MIN & MAX \\
\hline Altitude & Alt & 942 & 409 & 26 & 2172 & 1009 & 397 & 24 & 2281 \\
\hline Annual mean temperature & Bio01 & 10.93 & 2.53 & 3.40 & 16.00 & 10.15 & 2.11 & 3.70 & 16.00 \\
\hline $\begin{array}{l}\text { Mean diurnal range } \\
\text { [Mean of monthly (max temp-min temp)] }\end{array}$ & $\mathrm{Bio02}$ & 9.60 & 1.38 & 5.90 & 12.30 & 9.17 & 1.37 & 6.90 & 12.50 \\
\hline Isothermality $[(\mathrm{Bio} 2 / \mathrm{Bio} 7) \times 100]$ & $\mathrm{Bio03}$ & 3.63 & 0.24 & 3.00 & 4.50 & 3.61 & 0.29 & 2.90 & 4.30 \\
\hline Temperature seasonalit & io04 & 576.52 & 59.51 & 330.80 & 689.30 & 555 & 46.12 & 456.10 & 682.00 \\
\hline erature of warmest month & Bio05 & 25.83 & 3.40 & 16.20 & 34.10 & 24.37 & 2.35 & 16.60 & 30.90 \\
\hline erature of coldest month & Bio06 & -0.25 & 2.43 & -7.40 & 6.90 & -0.64 & 2.27 & -6.40 & 5.80 \\
\hline -Bio6) & $\mathrm{Bio} 07$ & 26.08 & 3.02 & 15.70 & 32.80 & 25.01 & 2.54 & 20.20 & 32.90 \\
\hline Mean & $\mathrm{Bio08}$ & 9.98 & 3.63 & 2.90 & 20.30 & 9.41 & 4.12 & 3.00 & 20.70 \\
\hline Mean & Bio09 & 14.01 & 7.72 & -2.40 & 24.20 & 11.37 & 7.15 & -2.00 & 22.90 \\
\hline Mean & Bio10 & 18.62 & 2.73 & 10.60 & 24.20 & 17.54 & 2.16 & 11.10 & 23.00 \\
\hline Mean temperature of coldest quarter & Bio11 & 3.98 & 2.46 & -3.10 & 10.10 & 3.45 & 2.11 & -2.50 & 9.50 \\
\hline Annual precipitation & io12 & 716.61 & 225.09 & 373.00 & 1280.00 & 829.35 & 152.00 & 432.00 & 1260.00 \\
\hline Precip & io13 & 85.36 & 26.18 & 44.00 & 178.00 & 96.86 & 15.12 & 53.00 & 139.00 \\
\hline & 1014 & 32.28 & 19.15 & 6.00 & 85.00 & 42.66 & 14.72 & 11.00 & 82.00 \\
\hline & Bio15 & 27.42 & 9.39 & 13.00 & 56.00 & 23.23 & 6.25 & 13.00 & 45.00 \\
\hline & Bio16 & 229.99 & 73.57 & 121.00 & 481.00 & 259.32 & 42.51 & 146.00 & 368.00 \\
\hline Precip & Bio17 & 121.39 & 57.80 & 34.00 & 291.00 & 153.23 & 44.44 & 50.00 & 283.00 \\
\hline Precipitation of warmest & & 139.24 & 70.75 & 34.00 & 294.00 & 175.51 & 55.36 & 50.00 & 298.00 \\
\hline Precipitation of coldest quarter & Bio19 & 180.88 & 74.33 & 73.00 & 477.00 & 201.13 & 52.50 & 101.00 & 362.00 \\
\hline
\end{tabular}


Table 4. Different measurements of climatic variables Worldclim and altitude in the points of presence and of high suitability for the Diplolepis eglanteriae/nervosa gall complex, with the average value (AV), standard deviation (SD) and minimum (MIN) and maximum (MAX) values for each.

\begin{tabular}{|c|c|c|c|c|c|c|c|c|c|}
\hline \multirow{2}{*}{ Variable } & \multirow{2}{*}{ Code } & \multicolumn{4}{|c|}{ PRESENCE DATA } & \multicolumn{4}{|c|}{ HIGH SUITABILITY } \\
\hline & & $\mathrm{AV}$ & SD & MIN & MAX & $\mathrm{AV}$ & SD & MIN & MAX \\
\hline Altitude & Alt & 869 & 485 & 3 & 1951 & 939 & 432 & -3 & 2292 \\
\hline Annual mean temperature & Bio01 & 11.13 & 2.82 & 3.50 & 17.10 & 9.97 & 2.44 & 2.50 & 16.40 \\
\hline $\begin{array}{l}\text { Mean diurnal range } \\
\text { [Mean of monthly (max temp-min temp)] }\end{array}$ & Bio02 & 9.29 & 1.51 & 5.90 & 12.10 & 8.74 & 1.18 & 5.80 & 12.20 \\
\hline Isothermality $[(\mathrm{Bio} 2 / \mathrm{Bio} 7) \times 100]$ & Bio03 & 3.67 & 0.29 & 3.10 & 4.50 & 3.66 & 0.29 & 2.90 & 4.50 \\
\hline Temperature seasonality (standard deviation $\times 100$ ) & Bio04 & 552.51 & 76.27 & 332.20 & 687.60 & 520.12 & 46.75 & 332.40 & 674.70 \\
\hline Max temperature of warmest month & Bio05 & 25.37 & 3.23 & 16.30 & 33.40 & 23.26 & 2.22 & 15.10 & 29.50 \\
\hline Min temperature of coldest month & Bio06 & 0.35 & 3.23 & -6.70 & 8.40 & -0.26 & 2.78 & -7.60 & 7.70 \\
\hline Temperature annual range (Bio5-Bio6) & Bio07 & 25.02 & 3.60 & 15.80 & 32.50 & 23.52 & 2.23 & 15.60 & 32.50 \\
\hline Mean temperature of wettest quarter & Bio08 & 9.72 & 3.72 & 2.00 & 19.00 & 8.49 & 3.74 & 1.70 & 19.20 \\
\hline Mean temperature of driest quarter & Bio09 & 14.01 & 7.44 & -0.90 & 23.60 & 12.56 & 6.79 & -2.40 & 23.10 \\
\hline Mean temperature of warmest quarter & Bio10 & 18.48 & 2.72 & 10.60 & 23.60 & 16.86 & 2.26 & 9.60 & 23.30 \\
\hline Mean temperature of coldest quarter & Bio11 & 4.45 & 3.08 & -2.80 & 12.00 & 3.65 & 2.64 & -3.70 & 10.20 \\
\hline Annual precipitation & Bio12 & 787.10 & 255.02 & 389.00 & 1484.00 & 908.00 & 155.44 & 508.00 & 1407.00 \\
\hline Precipitation of wettest month & Bio13 & 95.48 & 34.10 & 44.00 & 234.00 & 104.69 & 16.84 & 58.00 & 202.00 \\
\hline Precipitation of driest month & Bio14 & 34.07 & 19.98 & 3.00 & 81.00 & 48.22 & 13.48 & 12.00 & 88.00 \\
\hline Precipitation seasonality (coefficient of variation) & Bio15 & 28.48 & 11.78 & 13.00 & 66.00 & 21.17 & 5.14 & 13.00 & 51.00 \\
\hline Precipitation of wettest quarter & Bio16 & 258.12 & 93.85 & 127.00 & 597.00 & 282.09 & 45.54 & 159.00 & 564.00 \\
\hline Precipitation of driest quarter & Bio17 & 127.95 & 60.86 & 25.00 & 269.00 & 172.95 & 40.87 & 58.00 & 299.00 \\
\hline Precipitation of warmest quarter & Bio18 & 145.77 & 72.40 & 29.00 & 280.00 & 188.97 & 46.69 & 59.00 & 299.00 \\
\hline Precipitation of coldest quarter & Bio19 & 212.58 & 101.85 & 75.00 & 580.00 & 232.32 & 56.84 & 102.00 & 564.00 \\
\hline
\end{tabular}

Table 5. Different measurements of climatic variables Worldclim and altitude in the points of presence and of high suitability for Diplolepis mayri, with the average value (AV), standard deviation (SD) and minimum (MIN) and maximum (MAX) values for each.

\begin{tabular}{|c|c|c|c|c|c|c|c|c|c|}
\hline \multirow{2}{*}{ Variable } & \multirow{2}{*}{ Code } & \multicolumn{4}{|c|}{ PRESENCE DATA } & \multicolumn{4}{|c|}{ HIGH SUITABILITY } \\
\hline & & AV & SD & MIN & MAX & AV & SD & MIN & MAX \\
\hline Altitude & Alt & 956 & 406 & 21 & 2198 & 1110 & 370 & 10 & 2313 \\
\hline Annual mean temperature & Bio01 & 11.54 & 2.19 & 5.00 & 16.00 & 10.53 & 1.86 & 5.10 & 16.90 \\
\hline $\begin{array}{l}\text { Mean diurnal range } \\
\text { [Mean of monthly (max temp-min temp)] }\end{array}$ & Bio02 & 10.13 & 1.38 & 6.10 & 12.30 & 10.22 & 1.56 & 6.90 & 12.50 \\
\hline Isothermality $[(\mathrm{Bio} 2 / \mathrm{Bio} 7) \times 100]$ & Bio03 & 3.61 & 0.21 & 3.00 & 4.00 & 3.62 & 0.23 & 2.90 & 4.20 \\
\hline Temperature seasonality (standard deviation $\times 100$ ) & Bio04 & 606.60 & 48.93 & 367.00 & 689.30 & 607.78 & 40.56 & 495.30 & 678.80 \\
\hline Max temperature of warmest month & Bio05 & 27.40 & 2.75 & 18.20 & 33.50 & 26.42 & 2.37 & 18.60 & 33.20 \\
\hline Min temperature of coldest month & Bio06 & -0.16 & 2.28 & -5.10 & 6.60 & -1.27 & 2.18 & -6.00 & 5.60 \\
\hline Temperature annual range (Bio5-Bio6) & Bio07 & 27.57 & 2.86 & 16.20 & 32.80 & 27.69 & 2.89 & 21.80 & 32.80 \\
\hline Mean temperature of wettest quarter & Bio08 & 10.16 & 3.69 & 2.50 & 20.30 & 10.41 & 3.49 & 1.90 & 20.70 \\
\hline Mean temperature of driest quarter & Bio09 & 16.32 & 6.85 & -0.80 & 23.90 & 13.87 & 7.34 & -1.10 & 24.10 \\
\hline Mean temperature of warmest quarter & Bio10 & 19.68 & 2.22 & 12.50 & 24.00 & 18.69 & 1.83 & 12.40 & 24.30 \\
\hline Mean temperature of coldest quarter & Bio11 & 4.27 & 2.23 & -1.30 & 9.60 & 3.27 & 1.94 & -1.50 & 10.80 \\
\hline Annual precipitation & Bio12 & 602.94 & 169.22 & 351.00 & 1174.00 & 646.88 & 162.74 & 390.00 & 1139.00 \\
\hline Precipitation of wettest month & Bio13 & 73.64 & 19.34 & 47.00 & 129.00 & 79.30 & 16.81 & 47.00 & 137.00 \\
\hline Precipitation of driest month & Bio14 & 23.35 & 15.06 & 2.00 & 78.00 & 29.47 & 14.00 & 6.00 & 76.00 \\
\hline Precipitation seasonality (coefficient of variation) & Bio15 & 30.84 & 9.29 & 14.00 & 68.00 & 27.32 & 6.23 & 15.00 & 46.00 \\
\hline Precipitation of wettest quarter & Bio16 & 197.29 & 55.09 & 116.00 & 361.00 & 207.65 & 46.81 & 126.00 & 362.00 \\
\hline Precipitation of driest quarter & Bio17 & 92.82 & 45.93 & 20.00 & 258.00 & 111.28 & 42.62 & 35.00 & 248.00 \\
\hline Precipitation of warmest quarter & Bio18 & 107.20 & 62.47 & 24.00 & 278.00 & 129.49 & 56.94 & 35.00 & 291.00 \\
\hline Precipitation of coldest quarter & Bio19 & 153.56 & 50.28 & 80.00 & 349.00 & 151.89 & 45.18 & 77.00 & 349.00 \\
\hline
\end{tabular}

ages $>0.70$ ) for this species complex on the peninsula. The most suitable areas are characterized by an average mean annual temperature of $9.97^{\circ} \mathrm{C}$ and an annual precipitation of $908 \mathrm{~mm}$ (Table 4). The models indicate that the most suitable areas for these species are coastal areas in Galicia, Asturias, Cantabria, Basque Country and Catalonia and the mainland in Navarre and Aragon (northern Spain; Fig. 4B).

Diplolepis mayri (Figs 1A, B and G, 4C), like D. rosae, is common on the Iberian Peninsula. The mountainous areas in the central and south eastern parts of the peninsula are highly suitable for D. mayri (Table 5), with the Catalonian Pyrenees (north eastern Iberian Peninsula) the most suitable. These areas are the parts of the Iberian Peninsula with a Mediterranean climate.

Regarding the bioclimatic variables in the highly suitable areas for each species of Diplolepis (Tables 3, 4 and $5), D$. mayri is the species which can occur at higher altitudes (956 $\mathrm{m}$ a.s.l. on average) and D. eglanteriae/nervosa in areas with the highest rainfall (787.1 $\mathrm{mm}$ on average). Moreover, combining the potential distribution maps revealed suitable areas for all of the species of Diplolepis. There is a clear separation in the highly suitable areas for D. eglanteriae/nervosa and D. mayri (Fig. 5A), with those of the former mainly in the northern parts and the latter 

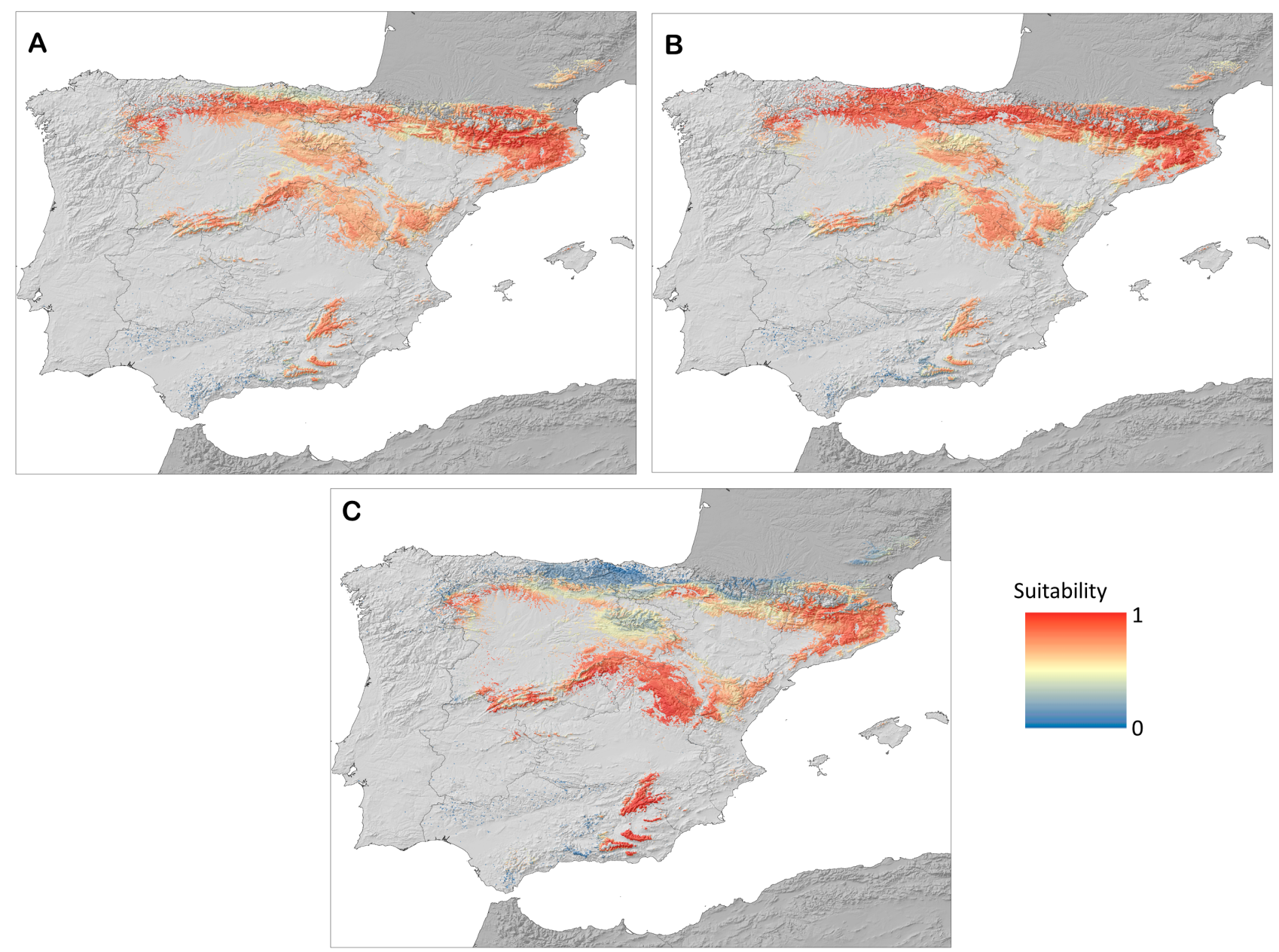

Suitability

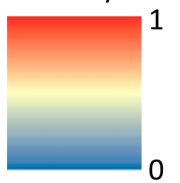

Fig. 4. Map of the suitable areas on the Iberian Peninsula for the species studied. A - Diplolepis rosae; B - Diplolepis eglanteriae/nervosa; C-Diplolepis mayri.

in of the central and southern parts of the Iberian Peninsula. The central mountain ranges are of low suitability for D. eglanteriae/nervosa and D. rosae, whereas the mountainous areas in the northern part of the Iberian Peninsula are the most favourable for them (Fig. 5B). The species D. rosae and D. mayri share the same potential distribution, with a small area in northern Catalonia region (north eastern Iberian Peninsula) with highest suitability for both species (Fig. 5C).

The distributions of species of Diplolepis seem to be associated with particular climatic variables (Fig. 6). The boxplots provide a visual approximation of the predictions of the models: areas highly suitable for $D$. mayri are in areas with higher temperatures and lower rainfall than those highly suitable for the other species of Diplolepis. It is also noted that $D$. eglanteriae/nervosa has the highest tolerance range for rainfall and $D$. rosae is the most generalist of the species (Fig. 6).

\section{DISCUSSION}

\section{Suitability models for the different species of Diplolepis}

The presence data indicate a greater occurrence of all the species of Diplolepis studied in the northern than in the southern part of the peninsula (Fig. 2). This may be because cynipids have been sampled less in southern Spain than in central and northern Spain (Nieves-Aldrey, 2001a). However, more recent samples collected from 2017 to 2019 by Nieves-Aldrey (unpubl. data) confirm that $D$. rosae is absent or less abundant in the southern part of the Iberian Peninsula. In addition, it is noteworthy that the records obtained from the citizen science platform Biodiversidad Virtual (BVdb, 2016), which were collected by many observers and make up $\sim 50 \%$ of the total records for species of Diplolepis (Table 1), few of these records are for the southern Iberian Peninsula. Moreover, many galls are striking structures that are specific to the inducer wasp, which makes them easily identifiable and photographic evidence of their presence at a particular place. Such georeferenced data can be used along with previously published records in biogeographical studies of the Iberian Peninsula (Goula et al., 2013; Jiménez-Valverde et al., 2019). Based on this information and that $D$. rosae is the most common species on the Iberian Peninsula, it is possible that the data truly reflect a latitudinal gradient in the abundance of these species on this Peninsula.

On the other hand, an important aspect of these models is the environmental conditions selected and their effects on the distribution of the species analysed. The insects studied are obligatorily dependent on their Rosa hosts, on 


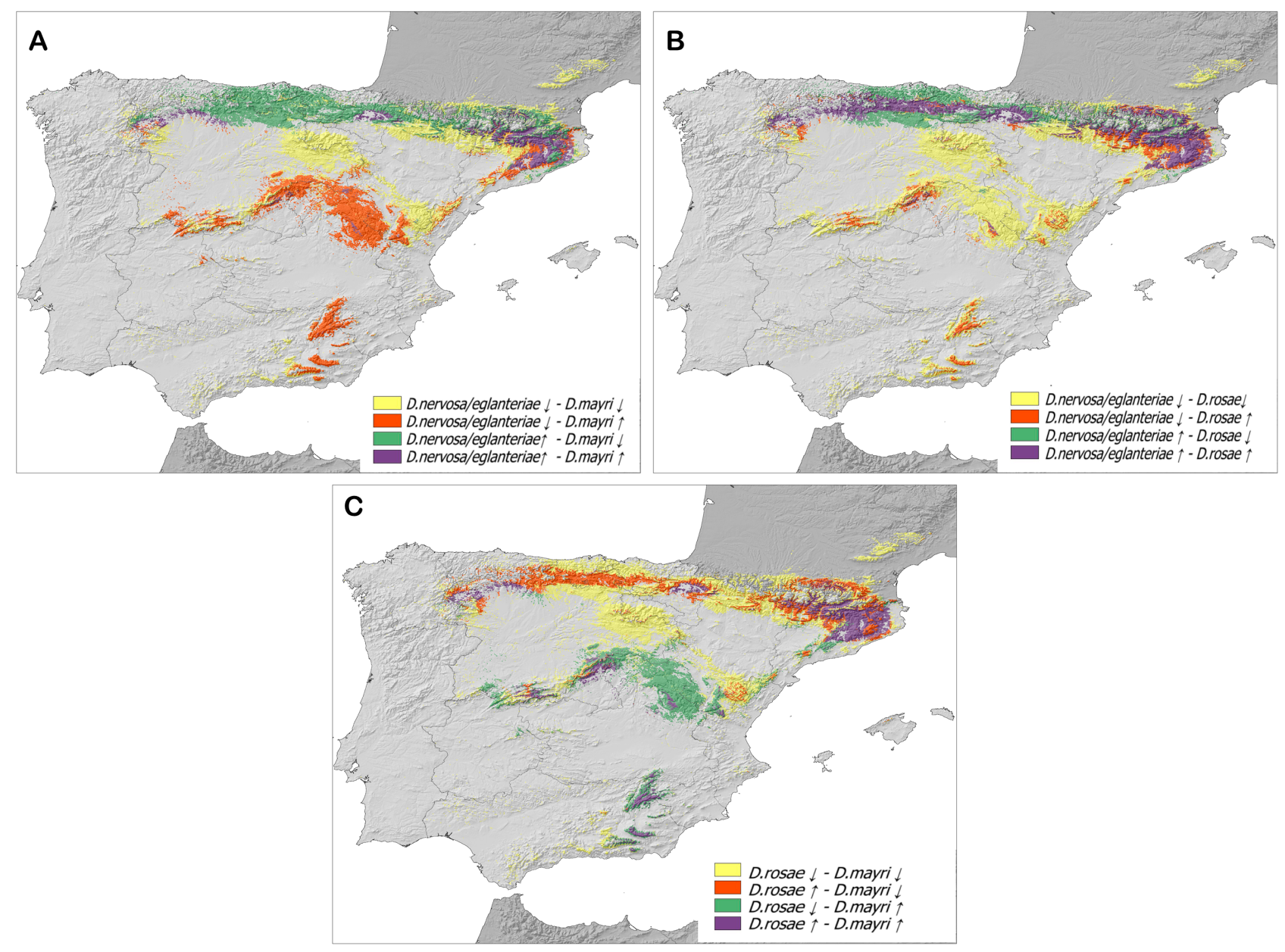

Fig. 5. Maps of the potential distributions of low $(\downarrow)$ and high $(\uparrow)$ suitable areas in the region studied for: A - the Diplolepis eglanteriae/ nervosa complex and Diplolepis mayri; B - Diplolepis eglanteriae/nervosa and Diplolepis rosae; C - Diplolepis rosae and Diplolepis mayri.

which they induce galls (Nieves-Aldrey, 2001a). Thus, the limiting variable is the distribution of their host plant. The suitability models developed for Rosa were constructed using all the data for wild rose plants, without considering host specificity or preference of each species of Diplolepis. Although there is currently no evidence of species of Diplolepis being host specific (Stille, 1984; Kohnen et al., 2011), except in the case of D. spinosissimae for R. pimpinellifolia, it is possible that the distributions of specific species of Rosa may be a factor affecting the distributions of these cynipids. There are 27 species of the genus Rosa on the Iberian Peninsula, which are highly polymorphic and hybrids are also present, making their identification by non-specialists difficult (Castroviejo, 1998; Cueto \& Giménez, 2009; Calvo \& Ross-Nadié, 2016; Tomljenović $\&$ Pejić, 2018). For this reason, and in addition to the fact that there are no reliable data on the distributions of species of Rosa, all the plant data used were at the genus rather than the species level.

Other variables not considered were the effects of habitat fragmentation due to natural and anthropogenic causes and the microhabitat or microtopographic conditions. Increasing land use intensity and habitat fragmentation are important threats to global biodiversity, especially in agricultural landscapes. Some studies report that landscape diversity has little or no effect on the species richness of Diplolepis (Looney \& Eigenbrode, 2010) and that the homogenization of the landscape provides a perfect habitat for gall inducers and their community members (László et al., 2018). On the other hand, microtopographic conditions can mask temperature differences along altitudinal or latitudinal gradients over small scales. The interaction between microtopography, plant cover and solar radiation result in microhabitat conditions that are not represented by climatic variables (Scherrer \& Körner, 2010, 2011; Scherrer et al., 2011).

Diplolepis rosae has a wider potential distribution than the rest of the species. For this reason, this species is found in most rose bushes on the Iberian Peninsula (Fig. 4A). Most of the $D$. rosae data used in the present article do not specify the sex of the galler or the composition and abundance of its parasitoid communities. However, in the summer of 2017, Nieves-Aldrey (unpubl. data) found a single male specimen of $D$. rosae in the Aracena Mountains in south western Iberian Peninsula (Nieves-Aldrey, 2001a). This observation matches those of other authors, which indicate the possibility of a latitudinal gradient (from south to north) in the sex ratio of this species. For example, Askew (1960) and Hoffmeyer (1925) suggest that there is a higher abundance of male $D$. rosae in the northern parts of the peninsula. However, some authors (Rizzo \& Massa, 2006; 

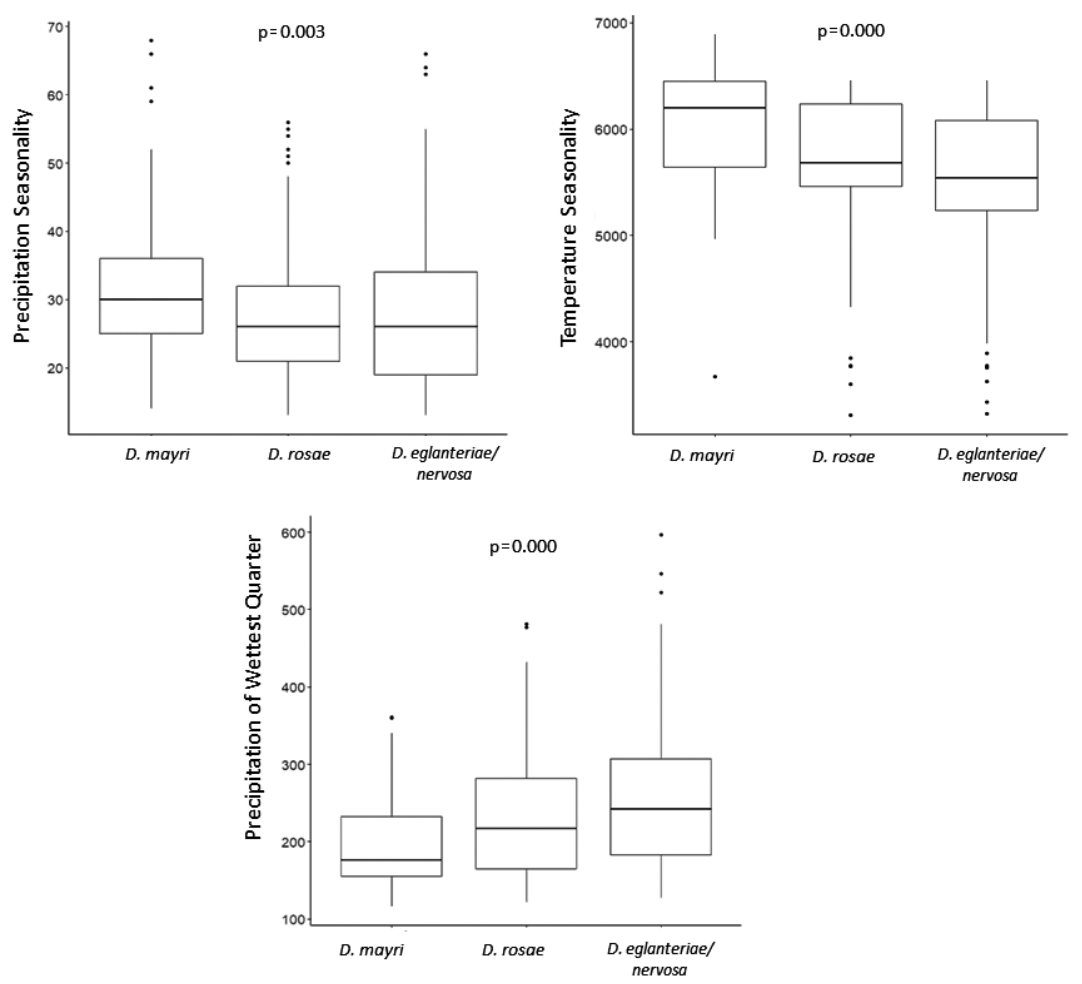

Fig. 6. Boxplots showing the associations between highly suitable areas $(>0.70)$ for the species of Diplolepis and three bioclimatic variables: precipitation seasonality (Bio15), temperature seasonality (Bio04) and precipitation in the wettest quarter (Bio16).

László \& Tóthmèrèsz, 2011; Todorov et al., 2012) report the lack of a latitudinal gradient and that the presence of D. rosae males depends on more complicated factors, and also that the endosymbiotic bacteria Wolbachia affect the sex ratio of this species (Schilthuizen \& Stouthamer, 1998; Rizzo \& Massa, 2006). The record of a male of D. rosae on the Iberian Peninsula indicates the presence of males in southern Europe, although at a low abundance. However, to determine the actual sex ratio of $D$. rosae, more intensive sampling is needed in southern Europe.

The D. eglanteriae/nervosa model (Fig. 4B) reveals that the presence data and the maximum suitability for these two species occur in mountain forest areas and they avoid river-valleys (Table 4). In addition, D. eglanteriae and $D$. nervosa are also abundant in areas near the northern coast of the Iberian Peninsula. It is possible that in mountainous areas, species of Rosa have local characteristics, e. g. separation of vegetation patches, shrub size, or distance to the soil, that are lacking in riverbanks, and that these conditions are favourable for both cynipid species. An example is provided by Mifsud (2016), who reports that in mountainous areas, where wild roses grow in the shade of conifer trees, they do not flower and galls are not recorded. On the other hand, mountainous areas, particularly mountain forests, are favourable in many other ways; for example, the spatial configuration of trees favours optimal radiation, temperature and precipitation conditions. The conditions found in mountainous areas, together with being isolated from other areas, may have resulted in there being more or different species of Rosa, which could be specific or more suitable hosts for $D$. eglanteriae and $D$. nervosa, than at lower altitudes. However, the host preference of these spe- cies of Diplolepis has not been determined due to the taxonomic difficulties of identifying each species of wild rose, among other reasons.

Diplolepis mayri occurs in the western Palearctic in areas of north Africa and Asia Minor (Nieves-Aldrey, 2001a). The distribution model for this species (Fig. 4C) revealed that the areas with the highest suitability were mainly in mountainous regions in the Mediterranean area of the Iberian Peninsula. Unlike D. rosae and D. eglanteriae/nervosa, there is an area of high suitability for $D$. mayri in the southern third of the Iberian Peninsula. This species is distributed in areas with relatively more precipitation seasonality and temperature seasonality, and relatively less rain (Fig. 6, Table 5). This might indicate that D. mayri is adapted to the Mediterranean climatic conditions in the southern Iberian Peninsula, unlike the rest of the species of Diplolepis studied.

\section{Habitat complementarity}

A comparison of the potential distributions of D. eglanteriae/nervosa and D. mayri revealed that they occur in complementary areas, e.g., areas on Iberian Peninsula with highly suitable environmental conditions for $D$. eglanteriae and D. nervosa are of low suitability for D. mayri and vice versa (Fig. 5A). This phenomenon occurs between species in other genera, such as Copris hispanus (Linnaeus, 1758) and Copris lunaris (Linnaeus, 1758) (Coleoptera: Scarabaeidae) (Chefaoui et al., 2004), different species of the red-striped oil beetle of the genus Berberomeloe Bologna, 1989 (Coleoptera: Meloidae) (Sánchez-Vialas et al., 2020) and among species that compete for resources (De Smedt et al., 2016). 
It is possible that the species of Diplolepis studied are allopatric. The areas of high suitability for $D$. eglanteriae and $D$. nervosa occur in the north of the Iberian Peninsula (Euro Siberian areas) and those for D. mayri in central and southern parts of the Iberian Peninsula (Mediterranean areas). These zones are separated by the northern plateau of the Iberian Peninsula where host plants are either absent or scarce. Studies on the structure and genetic diversity of these species are likely to reveal significant genetic differentiation between them, possibly due to this physical barrier. The molecular characteristics of the cytochrome $b$ and $12 \mathrm{~S}$ genes and different character states ('number of larval chambers per gall', 'organ bearing the gall' and 'surface area of the gall') of species of the Diplolepis reveals that the species included in our study form two species groups: the $D$. eglanteriae group (including $D$. eglanteriae and $D$. nervosa) and the $D$. rosae group (including $D$. rosae, $D$. fructuum, D. mayri and D. spinosissimae) (Plantard et al., 1997). Recently, Zhang et al. (2019) published a phylogeny of Diplolepis and Periclisttus based on COI (cytochrome c oxidase subunit I) that divides the genus Diplolepis into two major monophyletic clades, the 'flanged femur' clade and 'leaf galler' clade, the latter of which includes three subclades: the Nearctic leaf galler subclade, the Palearctic multichambered subclade and a mixed leaf gall subclade. The Palearctic multichambered subclade includes the $D$. rosae group (D. fructuum, D. mayri and D. rosae), D. spinosissimae and two undescribed species. Finally, the rest of the species included in our study are classified in the mixed leaf gall subclade, which distinguishes between the $D$. eglanteriae Palearctic group (D. japonica and D. eglanteriae) and the $D$. eglanteriae Nearctic group and $D$. nervosa. The different lineages of the subclades that contain D. mayri and D. rosae (Palaearctic multichambered subclade) and D. eglanteriae and D. nervosa (mixed leaf gall subclade) could partially explain the observed habitat complementarity between $D$. mayri and $D$. eglanteriae/ nervosa.

There is an overlap in the most suitable areas for Diplolepis eglanteriae/nervosa and D. rosae in the northern mountain ranges (Fig. 5B); therefore, there could potentialy be interspecific competition between these species in this area. However, D. rosae and D. eglanteriae/nervosa exploit their host plants in different ways. Diplolepis eglanteriae/nervosa induce galls on the petioles or undersides of leaves and $D$. rosae on the buds of the stems, leaflets or fruits (Nieves-Aldrey, 2001a). It is possible that if two different species have overlapping distributions, they might use different parts of the same resource or develop strategies that allow them to exploit the same resource without competing. For example, the distributions of other Hymenoptera [Apis mellifera (Linnaeus, 1758) and Bombus terrestris (Linnaeus, 1758)] also largely overlap with respect to the plants they pollinate; however, their pollination activities have different schedules (Perez, 2013). For the two species with most records (D. rosae and D. mayri), the most suitable areas occur in the north eastern and central parts of the Iberian Peninsula (Fig. 5C) where they overlap the suitable habitat for $D$. eglanteriae/nervosa, as mentioned above.

\section{An overview of the distribution of Diplolepis in Europe}

Focusing on the western Palearctic, the glaciation events in the Quaternary/Pleistocene are considered to be a key determinant of the distribution of plants and therefore that of cynipids (Taberlet et al., 1998; Hewitt 1999; Rokas et al., 2003; Stone et al., 2001; Güçlü et al., 2008). Like the Iberian Peninsula, the Anatolian Peninsula was also a glacial refugium during the European glaciations and have a rich fauna, including cynipids of the genus Diplolepis. Therefore, a comparative study of these two peninsulas, with either similar or parallel scenarios, can be used to define the evolutionary history of this group in the western Palearctic. In addition, the Anatolian Peninsula is the transition point between the continents of Europe, Asia and Africa, and has a great variety of natural habitats, ranging from Mediterranean, Aegean and Black Sea beaches to towering coastal and interior mountains, including deeply incised valleys, expansive steppes and fertile alluvial plains along with arid, rocky slopes. Ronquist \& Liljeblad (2001) report that many of the ancestral cynipid relationships occur in the eastern Mediterranean and Turano-Eremial region, indicating that this area was possibly the centre of speciation for cynipid gallers (Mete \& Demirsoy, 2012).

The absence of $D$. fructuum from the Iberian Peninsula (the only other species of western Palearctic Diplolepis missing in this territory) and the presence of all the European species of this genus on the Anatolian Peninsula seem to indicate an east-west gradient in the richness of species of cynipids. In the past, D. fructuum was considered a geographic race of $D$. mayri, but molecular techniques confirm they are different species (Plantard et al., 1997; Güçlü et al., 2008; Zhang et al., 2019). It is possible that Diplolepis spread from eastern Europe to the west; in this case, the Iberian Peninsula is the western limit to the distribution of this genus, with greater species richness in the Nearctic and eastern Palearctic regions.

In the case of the suitable areas for D. eglanteriae and $D$. nervosa there are similarities between the Anatolian and Iberian peninsulas. The most suitable areas on the Iberian Peninsula for Diplolepis eglanteriae/nervosa are around high-altitude large mountain ranges. This is also the case on the Anatolian Peninsula, where D. eglanteriae and D. nervosa occur in provinces enclosed by mountain ranges at altitudes greater than 2,000 m (Güçlü et al., 2008; Katılmıs \& Kryak, 2010; Mete \& Demirsoy, 2012). This supports the hypothesis that both the Iberian and Anatolian Peninsulas were Pleistocene glacial refugia of these species. In addition, D. eglanteriae and $D$. nervosa spread from western Asia into Europe along major mountain ranges, such as the Carpathians in Romania, Serbia and the Ukraine (Melika, 2006; Marković, 2015; Prázsmári et al., 2017), Malta (Mifsud, 2016) and the Scandinavian Mountains at their northern latitudinal limit (Bergqvist, 2010). Based on these facts and our distribution models, which indicate that $D$. eglanteriae and D. nervosa occur in the Eurosiberian 
region, it is likely that glaciation events may have limited the distributions of these species, which were able to adapt to cold and high-altitude conditions (Fig. 6, Table 4). On the other hand, D. rosae seems to have been able to spread and adapt to different temperate conditions (Table 3), although the scarcity of this species in the southern parts of the Iberian Peninsula seems to indicate it has a Euro Siberian distribution. Diplolepis mayri seems to have an affinity for Mediterranean conditions as the highly suitable areas for this species are on the southern plateau of the Iberian Peninsula and complementary to those of D. rosae and Diplolepis eglanteriae/nervosa.

ACKNOWLEDGEMENTS. We would like to thank MNCN-CSIC, Biodiversidad Virtual and the Department of Biodiversity, Ecology and Evolution of Complutense University for their collaboration in the collection of presence data for species of Diplolepis and all the information they provided us on these cynipids.

\section{REFERENCES}

Abe Y., Melika G. \& Stone G.N. 2007: The diversity and phylogeography of cynipid gallwasps (Hymenoptera: Cynipidae) of the oriental and eastern Palearctic regions, and their associated communities. - Orient. Insects 41: 169-212.

Araújo M.B. \& Guisan A. 2006: Five (or so) challenges for species distribution modelling. - J. Biogeogr. 33: 1677-1688.

Askew R.R. 1960: Some observations on Diplolepis rosae (L.) (Hym. Cynipidae) and its parasites. - Entomol. Mon. Mag. 95: 191-192.

Austin M.P. 2007: Species distribution models and ecological theory: a critical assessment and some possible new approaches. - Ecol. Model. 200: 1-19.

Barbet-Massin M., Rome Q., Muller F., Perrard A., Villemant C. \& JiGUET F. 2013: Climate change increases the risk of invasion by the yellow-legged hornet. - Biol. Conserv. 157: 4-10.

Belizin V.I. 1957: Gall wasps (Hymenoptera: Cynipidae) in the USSR fauna developed on roses. - Entomol. Obozr. 36: 925934.

Bergqvist E. 2010: Sawflies and Wasps Attacking Roses. First cycle, G1E. Department of Plant Protection Biology, Swedish University of Agricultural Sciences, Alnarp, 42 pp. [in Swedish].

BVdb (Biodiversidad Virtual Database) 2016: Insectarium Virtual. Genus Diplolepis. URL: http://www.biodiversidadvirtual. org/insectarium (last accessed 20 Sep. 2016).

Breiman L. 2001: Random forests. - Machi. Learn. 45: 5-32.

Breiman L., Cutler A., LiaW A. \& Wiener M. 2015: Breiman and Cutler's Random Forests for Classification and Regression (R Package Ver. 4.6-12). URL: https://cran.r-project.org/web/ packages/randomForest/.

BurKs B.D. 1979: Superfamily Cynipoidea. In Krombein K.V., Hurd P.D., Smith Jr. D.R. \& Burks B.D. (eds): Catalog of Hymenoptera in America North of Mexico, Vol. 1. Smithsonian Institution Press, Washington, pp. 1045-1107.

Calvo J. \& Ross-Nadié E. 2016: Rosas silvestres ibéricas. Guía de identificación. Consejo Superior de Investigaciones Científicas, Madrid, $70 \mathrm{pp}$.

Castroviejo S., Muñoz Garmendia F. \& Navarro C. 1998: Flora Ibérica: Plantas vasculares de la Península Ibérica e Islas Baleares. Vol. VI. Rosaceae. Real Jardín Botánico, CSIC, Madrid, $592 \mathrm{pp}$.

Chefaoui R.M., Hortal J. \& Lobo J.M. 2004: Potential distribution modelling, niche characterization and conservation status assessment using GIS tools: a case study of Iberian Copris species. - Biol. Conserv. 122: 327-338.

Codina A. 1920: Recull de zoocecidies catalanes. - Butl. Inst. Catalana Hist. Nat. 20: 178-187 [in Catalan].

Cogolludo J. 1921: Contribución al conocimiento de las zoocecidias de España. - Trab. Mus. Nac. Cienc. Nat. (Ser. Bot.) 16: $1-117$.

Csóka G., Stone G.N. \& Melika G. 2005: The biology, ecology and evolution of gall wasps. In Raman A., Schaefer C.W. \& Withers T.M. (eds): Biology, Ecology and Evolution of GallInducing Arthropods. Science Publisher, Enfield, New Hampshire, pp. 573-642.

Cueto M. \& Giménez E. 2009: Family Rosaceae. In Blanca G., Cabezudo B., Cueto M., Fernández López C. \& Morales Torres C. (eds): Flora Vascular de Andalucía Oriental. Universidades de Almería, Jaén y Málaga, Granada, pp. 869-904.

De Smedt P., Wuyts K., Baeten L., De Schrijver A., Proesmans W., De Frenne P., Ampoorter E., Remy E., Gijbels M., Hermy M. ET AL. 2016: Complementary distribution patterns of arthropod detritivores (woodlice and millipedes) along forest edgeto-interior gradients. - Insect Conserv. Divers. 9: 456-469.

EEA (European ENVIRonment Agency) 2009: WISE Large Rivers and Lakes Raster Data. URL: https://www.eea.europa.eu/dataand-maps/data/wise-large-rivers-and-large-lakes (last accessed Jan. 2018).

EEA (European Environment Agency) 2012: Corine Land Cover 2006 Raster Data. URL: https://www.eea.europa.eu/data-andmaps/data/clc-2006-raster (last accessed Jan. 2018).

ESDB (European Soll DatabaSe) 2004: The European Soil Database Distribution Ver. 2.0. URL: https://esdac.jrc.ec.europa. eu/content/european-soil-database-v20-vector-and-attributedata\#tabs-0-description=0 (last accessed Jan. 2018).

ESRI (Environmental Systems Research Institute) 2011: ArcGis 10.1 Geographical Information System. URL: https:// www.esri.com/es-es/home (last accessed Jan. 2018).

FernándeZ de Gata M. 1901: Nuevos estudios sobre las agallas. - Bol. R. Soc. Esp. Hist. Nat. 1: 194-199, 231-331, 345-353, 385-402.

Folliot R. 1964: Contribution à l'étude de la biologie des cynipides gallicoles (Hymenoptères, Cynipoidea). - Ann. Sci. Nat. (Zool. Sér. 12) 6: 402-564.

Franklin J. 2009: Mapping Species Distributions: Spatial Inference and Prediction. Cambridge University Press, Cambridge, UK, $320 \mathrm{pp}$.

GBIF Data Portal 2016: Genus Diplolepis. URL: https://www. gbif.org/ (last accessed 20 Sep. 2016).

Gil-Tapetado D., Gómez J.F., Cabrero-Sañudo F.J. \& NievesAldREY J.L. 2018: Distribution and dispersal of the invasive Asian chestnut gall wasp, Dryocosmus kuriphilus (Hymenoptera: Cynipidae), across the heterogeneous landscape of the Iberian Peninsula. — Eur. J. Entomol. 115: 575-586.

Goula M., Sesma J.M. \& Vivas L. 2013: Photosharing websites may improve Hemiptera biodiversity knowledge and conservation. - ZooKeys 319: 93-105.

Guisan A. \& Zimmermann N.E. 2000: Predictive habitat distribution models in ecology. - Ecol. Model. 135: 147-186.

Guisan A., Lehmann A., Ferrier S., Austin M., Overton J.M.C., Aspinall R. \& Hastie T. 2006: Making better biogeographical predictions of species' distributions. - J. Appl. Ecol. 43: 386-392.

Güçlü S., Hayat R., Shorthouse J.D. \& Tozlu G. 2008: Gallinducing wasps of the genus Diplolepis (Hymenoptera: Cynipidae) on shrub roses of Turkey. - Proc. Entomol. Soc. Wash. 110: 204-217. 
Hastie T.J. \& TibshiRAni R.J. 1990: Generalized Additive Models. Chapman \& Hall, London, 335 pp.

Heiberger R.M. \& Holland B. 2015: Statistical Analysis and Data Display: An Intermediate Course with Examples in R (1st and 2 nd ed.). Springer Text in statistics. URL: https://cran.rproject.org/web/packages/HH/index.html

HewitT G.M. 1999: Post-glacial re-colonization of European biota. - Biol. J. Linn. Soc. 68: 87-112.

Hijmans R.J., Cameron S.E., Parra J.L., Jones P.G. \& Jarvis A. 2005: Very high resolution interpolated climate surfaces for global land areas. - Int. J. Climatol. 25: 1965-1978.

Hijmans R.J., Phillips S., Leathwick J. \& Elith J. 2015: Dismo. Species Distribution Modeling. (R Package Ver. 1.1-1). URL: https://CRAN.R-project.org/package=dismo.

HOFFMEYER E.B. 1925: Remarks on Danish gall wasps. - Entomol. Medd. 16: 1-8 [in Danish].

IGME (Instituto Geográfico y Minero Español) 2020: Lithology Layer. URL: http://info.igme.es/catalogo/catalog.aspx?po $\mathrm{rtal}=1 \&$ catalog $=3 \& \mathrm{ctt}=1 \&$ lang $=$ spa $\&$ dlang $=$ eng \&llt $=$ dropdo wn\&master $=$ infoigme $\&$ shdt $=$ false $\&$ shfo $=$ false $\&$ types $=3$ (last accessed 6 June 2020).

Jiménez-Valverde A., Peterson A.T., Soberón J., Overton J.M., Aragón P. \& LoBo J.M. 2011: Use of niche models in invasive species risk assessments. - Biol. Invas. 13: 2785-2797.

Jiménez-Valverde A., Peña-Aguilera P., Barve V. \& BurguilloMADRID L. 2019: Photo-sharing platforms key for characterising niche and distribution in poorly studied taxa. - Insect Conserv. Divers. 12: 389-403.

Katilmis Y. \& KiYAK S. 2010: Distribution, phenology and effects of Diplolepis spp. (Hymenoptera: Cynipidae) on Rosa canina in the Inland Western Anatolian. - J. Entomol. Res. Soc. 12(2): 31-36.

Kohnen A., Wissemann V. \& Brandl R. 2011: No host associated differentiation in the gall wasp Diplolepis rosae (Hymenoptera: Cynipidae) on three dog rose species. - Biol. J. Linn. Soc. 102: 369-377.

Koopman W.J.M., Wissemann V., De Cock K., Van HuylenbroeCK J., De Riek J., Sabatino G.J.H., Visser D., Vosman B., Ritz C.M., MAes B. ET AL. 2008: AFLP markers as a tool to reconstruct complex relationships: a case study in Rosa (Rosaceae). - Am. J. Bot. 95: 353-366.

Kutner M.H., Nachtsheim C., Neter J. \& Li W. 2004: Applied Linear Regression Models. McGraw Hill, New York, 1396 pp.

LÁszló Z. \& TóthMérész B. 2011: Parasitism, phenology and sex ratio in galls of Diplolepis rosae in the Eastern Carpathian Basin. - Entomol. Romanica 16: 33-38.

LÁszló Z., RÁkosy L. \& Tóthmérész B. 2018: The simpler the better: when decreasing landscape complexity increases community stability. - Ecol. Indic. 84: 828-836.

LÁzAro e IBIZA B. 1917: Noticias de algunas agallas de España. In Asociación Española para el Progreso de las Ciencias, Congreso de Valladolid, Sección 4, Ciencias Naturales. Imprenta de Fortanet, Madrid, pp. 5-55.

Lin D., Foster D.P. \& Ungar L.H. 2011: VIF-Regression: A fast regression algorithm for large data. - J. Am. Stat. Assoc. 493: 232-247.

LoONEy C. \& Eigenbrode S.D. 2010: Landscape-level effects of cynipid component communities of "orphaned" native shrubs. - J. Insect Conserv. 15: 695-706.

Lotfalizadeh H., Rasplus J.Y. \& Delvare G. 2006: Rose gall wasps and their associated fauna (Hymenoptera) in Iran. Redia 89: 73-85.

MARKović Č. 2015: Contribution to knowledge of the cynipid gall wasp (Hymenoptera: Cynipidae) fauna of Mt. Rtanj (Serbia). - Acta Entomol. Serb. 20: 137-143.
McCullagh P. \& Nelder J.A. 1989: Generalized Linear Models. Chapman \& Hall, London, 532 pp.

Melika G. 2006: Gall wasps of Ukraine. Cynipidae. - Vestn. Zool. 21: 301-644.

Mete Ö \& Demirsoy A. 2012: A preliminary study on the gallwasp fauna of Kemaliye (Erzincan, Turkey) and a new record for Turkey. - Hacettepe J. Biol. Chem. (Suppl.) 2012: 351363.

MifsUd S. 2016: Rediscovery of a rare gall on Rosa sempervirens induced by Diplolepis eglanteriae (Hartig, 1840) (Hymenoptera, Cynipidae) in Malta. - Bull. Entomol. Soc. Malta 8: $39-45$.

Nieves-AldRey J.L. 1981: Datos sobre Diplolepis rosae (L.) (Hym., Cynipidae) y su fauna de himenópteros parásitos en Salamanca. — Boln. Asoc. Esp. Entomol. 4: 107-113.

Nieves-AldRey J.L. 1984: Contribución al conocimiento de la fauna de himenópteros inquilinos y parásitos en las agallas de Diplolepis mayri (Schlechtendal) y Diplolepis eglanteriae (Hartig) (Hym., Cynipidae). — Graellsia 39: 93-102.

Nieves-Aldrey J.L. 1985: Notas sobre los Aylaxini (Hym., Cynipidae, Cynipinae) de la Península Ibérica, con descripción de una nueva especie de Isocolus. — Eos 60: 235-250.

Nieves-AldRey J.L. 1986: La colección de cinípidos gallícolas (Hym., Cynipidae, Cynipinae) del Instituto Español de Entomología. - Graellsia 41: 113-124.

Nieves-AldREy J.L. 1989: Los cinípidos gallícolas e inquilinos de la Sierra de Guadarrama y zonas adyacentes (Hym., Cynipidae). - Eos 64: 125-163.

NiEves-Aldrey J.L. 1995: Abundancia, diversidad y dinámica temporal de cinípidos en dos hábitats del centro de España (Hymenoptera, Cynipidae). In Avances en Entomología Ibérica: VI Congreso Ibérico de Entomología. Museo Nacional de Ciencias Naturales (CSIC), Universidad Autónoma de Madrid, Madrid, pp. 113-136.

Nieves-Aldrey J.L. 2001a: Fauna Ibérica, Vol. 16, Hymenoptera: Cynipidae. Consejo Superior de Investigaciones Científicas (CSIC), Madrid, $636 \mathrm{pp}$.

Nieves-AldREY J.L. 2001b: Nuevos datos faunísticos, corológicos y biológicos sobre los cinípidos del ámbito íbero-balear (Hymenoptera, Cynipidae). - Graellsia 57: 39-72.

Nieves-AldRey J.L. 2012: Two new herb gall wasps from Spain, including the description of a new species of Aulacidea Ashmead, 1897 (Hymenoptera, Cynipidae, "Aylacini”) inducing galls on Serratula nudicaulis L. DC (Asteraceae). - Graellsia 68: $325-339$.

Nieves-Aldrey J.L., Gómez J.F., Hernández Nieves M. \& Lobo J.M. 2006: Los Cynipidae (Hymenoptera) de la Comunidad de Madrid: lista anotada, mapas de distribución, riqueza y estatus de conservación. - Graellsia 62: 371-403.

O'Brien R.M. 2007: A caution regarding rules of thumb for variance inflation factors. - Qual. Quant. 41: 673-690.

Pérez V. 2013: Bombus (Bombus) terrestris (Linnaeus, 1758) (Hymenoptera: Apidae) introduction in the Magellan region: potential risk for the native bees. - An. Inst. Patagon. 41: 147-152.

Peterson A.T. 2006: Uses and requirements of ecological niche models and related distributional models. - Biodiv. Informatics 3: 59-72.

Peterson A.T., Soberón J., Pearson R.G., Anderson R.P., Martínez-MeYer E., NaKamura M. \& Araújo M.B. 2011: Ecological Niches and Geographical Distributions: A Modeling Perspective. Princeton University Press, Princeton, 328 pp.

PHILLIPS S.J. \& DUDIK M. 2008: Modeling of species distributions with Maxent: new extensions and a comprehensive evaluation. - Ecography 31: 161-175. 
Phillips S.J., Anderson R.P. \& Schapire R.E. 2006: Maximum entropy modelling of species geographic distributions. - Ecol. Model. 190: 231-259.

Plantard O., Shorthouse J.D. \& Rasplus J.Y. 1997: Molecular phylogeny of the genus Diplolepis (Hymenoptera: Cynipidae). In Csóka G., Mattson G., Stone W.J. \& Price P.W. (eds): The Biology of Gall Inducing Arthropods. USDA Forest Service, North Central Forest Experiment Station, Saint Paul, MN, pp. 247-260.

Prázsmári H., MÁtis A. \& LÁszló Z. 2017: Eurytoma caninae (Hymenoptera: Eurytomidae) in the parasitoid community of unilocular Diplolepis galls in the Carpathian Basin. - Folia Entomol. Hung. 78: 91-96.

Pujade-Villar J. 1983: Algunas consideraciones sobre Diplolepis rosae y Diplolepis mayri (Schlechtendal) en Cataluña (Hymenoptera, Cynipoidea, Cynipidae, Cynipinae). In: Actas del Primer Congreso Ibérico de Entomología, León 2. Servicio de Publicaciones de la Universidad de León, pp. 613-622.

Pujade-VIllar J. 1987: Organografía i malalties del cecidi de $D i$ astrophus rubi (Bouché, 1834) Harting, 1840 (Hymenoptera: Cynipoidea) a la tija d'esbarzer, Rubus caesius L. (Rosaceae). - Butll. Inst. Catal. Hist. Nat. 54(6): 65-71 [in Catalan].

Pujade-VILlar J. 1991: Contribució al coneixement dels cinipids cecidógens dels arbres $i$ arbusts de Catalunya dels cinipids associats a aquests $i$ dels seus paràsits. $\mathrm{PhD}$ thesis, Universidad de Barcelona, Barcelona, 1128 pp. [in Catalan].

Pujade-Villar J. 1993: Revisió de les espècies del gènere Diplolepis de l'Europa centro-occidental (Hym., Cynipidae) amb una especial atenció a la Península Ibérica. - Historia Animalium 2: 57-76 [in Catalan].

Pujade-Villar J. 1996: Zoocecids presents a les fulles de fagàcies andorranes, causats per cinípids (Hym., Cynipidae). - Annals Inst. Estud. Andorrans (Centre de Barcelona) 1994: 79-102 [in Catalan].

Pujade-Villar J., Wang Y., Zhang W., Mata-Casanova N., Lobato-Vila I., Dénes A.L. \& László Z. 2020: A new Diplolepis Geoffroy (Hymenoptera, Cynipidae, Diplolepidini) species from China: a rare example of a rose gall-inducer of economic significance. - ZooKeys 904: 131-146.

R Development Core Team 2008: $R$ : A Language and Environment for Statistical Computing $R$ Foundation for Statistical Computing. URL: https://www.r-project.org/ (last accessed Jan. 2018)

Rizzo M.C. \& Massa B. 2006: Parasitism and sex ratio of the bedeguar gall wasp Diplolepis rosae (L.) (Hymenoptera: Cynipidae) in Sicily (Italy). - J. Hymenopt. Res. 15: 277-285.

Rodríguez A., Gómez J.F. \& Nieves-Aldrey J.L. 2015: Modeling the potential distribution and conservation status of three species of oak gall wasps (Hymenoptera: Cynipidae) in the Iberian range. - J. Insect Conserv. 19: 921-934.

Rokas A., Atkinson R.J., Webster L.M.I., Csöka G. \& Stone G.N. 2003: Out of Anatolia: longitudinal gradients in genetic diversity support an eastern origin for a circum-Mediterranean oak gall wasp Andricus quercustozae. - Mol. Ecol. 12: 21532174.

RonQuist F. 1999: Phylogeny, classification and evolution of the Cynipoidea. - Zool. Scr. 28: 139-164.

RonQuist F. \& LILJEBLAD J. 2001: Evolution of the gall wasp host plant association. - Evolution 55: 2503-2522.

RStudio TeAm 2016: RStudio: Integrated Development for $R$ RStudio. URL: https://www.rstudio.com/ (last accessed Jan. 2018).

Sánchez-Vialas A., García-París M., Ruiz J.L. \& Recuero E. 2020: Patterns of morphological diversification in giant Berberomeloe blister beetles (Coleoptera: Meloidae) reveal an unexpected taxonomic diversity concordant with mtDNA phylogenetic structure. - Zool. J. Linn. Soc. 20: 1-64.

SCHERRER D. \& KöRNER C. 2010: Infra-red thermometry of alpine landscapes challenges climatic warming projections. - Glob. Chang. Biol. 16: 2602-2613.

SCHERRER D. \& KöRNER C. 2011: Topographically controlled thermalhabitat differentiation buffers alpine plant diversity against climate warming. - J. Biogeogr. 38: 406-416.

ScherRer D., Schmid S. \& KorNer C. 2011: Elevational species shifts in a warmer climate are overestimated when based on weather station data. - Int. J. Biometeorol. 55: 645-654.

Schilthuizen M. \& Stouthamer R. 1998: Distribution of Wolbachia among the guild associated with the parthenogenetic gall wasp Diplolepis rosae. - Heredity 81: 270-274.

SHORTHOUSE J.D. 1973: The insect community associated with rose galls of Diplolepis polita (Cynipidae, Hymenoptera). Quaest. Entomol. 9: 55-98.

Shorthouse J.D., Zuchlinski J.A. \& COURTIN G.M. 1980: Influence of snow cover on the overwintering of three species of gallforming Diplolepis (Hymenoptera: Cynipidae). - Can. Entomol. 112: 225-229.

Shorthouse J.D. \& Rohfritsch O. 1992: Biology of Insect-Induced Galls. Oxford University Press, London, $296 \mathrm{pp}$.

Søмme L. 1964: Effects of glycerol on cold-hardiness in insects. - Can. J. Zool. 42: 87-101.

STILLE B. 1984: The effect of host plant and parasitoids on the reproductive success of the parthenogenetic gall wasp Diplolepis rosae (Hymenoptera: Cynipidae). - Oecologia 63: 364-369.

STILle B. 1985: Population genetics of the parthenogenetic gall wasp Diplolepis rosae (Hymenoptera, Cynipidae). — Genetica 67: 145-151.

Stone G.N., Atkinson R., Rokas A., Csóka G. \& Nieves-Aldrey J.L. 2001: Differential success in northwards range expansion between ecotypes of the marble gallwasp Andricus kollari: a tale of two lifecycles. - Mol. Ecol. 10: 761-778.

Taberlet P., Fumagalli L., Wust-Saucy A.G. \& Cosson J.F. 1998: Comparative phylogeography and postglacial colonization routes in Europe. - Mol. Ecol. 7: 453-464.

Tavares J. DA S. 1931a: Cynipidae Peninsulae Ibericae, I. By the author, Lisboa, $5+315$ pp. [in Portuguese].

TaVares J. DA S. 1931b: Cynipidae Peninsulae Ibericae, II. By the author, Lisboa, $4+131$ pp. [in Portuguese].

Todorov I., Stojanova A., Parvanov D. \& Boyadzhiev P. 2012: Studies on the gall community of Diplolepis rosae (Hymenoptera: Cynipidae) in Vitosha Mountain, Bulgaria. - Acta Zool. Bulg. 4: 27-37.

Tomljenovic N. \& PejIĆ I. 2018: Taxonomic review of the genus Rosa. - Agric. Conspec. Sci. 83: 139-147.

Ventalló D. 1905: Algunas zoo-cecidias de Tarrassa. - Butll. Inst. Catal. Hist. Nat. 1905(5): 65 [in Catalan].

VILARRÚBiA A. 1936: Les zoocecidies de les plantes de Catalunya. - Trevalls Mus. Cienc. Natl. Barcelona 11(10): 1-106 [in Catalan].

VilarRúBIA A. \& Vilarrúbia L. 1933: Recull de zoocedies vigatanes. - Butll. Inst. Catal. Hist. Nat. 33: 232-240 [in Catalan].

VyrzhiKovsKaYA A.V. 1963: New gall wasps (Hymenoptera: Cynipidae) from Dog-rose in Central Asia and Kazakhstan. - Entomol. Obozr. 42: 651-659 [in Russian].

Williams J.B., Shorthouse J.D. \& Lee R.R. Jr. 2003: Deleterious effects of mild simulated overwintering temperatures on survival and potential fecundity of rose-galling Diplolepis wasps (Hymenoptera: Cynipidae). - J. Exp. Zool. 298: 23-31.

Wood S.N. 2016: mgcv: Mixed GAM Computation Vehicle with GCV/AIC/REML Smoothness Estimation (R Package Ver. 1.812). URL: http://CRAN.R-project.org/package $=$ mgcv 
Yan Z.F., Dolstra O., Hendriks T., Prins T.W., Stam P. \& Visser P.B. 2005: Vigour evaluation for genetics and breeding in rose. - Euphytica 145: 339-347.

Yee T.W. \& Mitchell N.D. 1991: Generalized additive models in plant ecology. - J. Veg. Sci. 2: 587-602.

Zimmermann N.E., Edwards T.C., Graham C.H., Pearman P.B. \& SvENNING J.C. 2010: New trends in species distribution modeling. - Ecography 33: 985-989.

ZhaNG D. \& GANDELIN M.H. 2003: Cultivar identification by image analysis. In Roberts A.V., Debener T. \& Gudin S. (eds): Encyclopedia of Rose Science. Vol. 1. Elsevier, London, pp. 124-135.
Zhang Y.M., Lászlo Z., LoOney C., Dénes A.L., Hanner R. \& Shorthouse J.D. 2019: DNA barcodes reveal inconsistent species boundaries in Diplolepis rose gall wasps and their Periclistus inquilines (Hymenoptera: Cynipidae). - Can. Entomol. 151: 717-727.

Received June 9, 2020; revised and accepted December 16, 2020 Published online February 5, 2021

Supplementary file:

Table S1 (http://www.eje.cz/2021/004/S01.xlsx). Georeferenced records of species of Diplolepis. 